\title{
CHANGES IN THE SOIL NITROGEN CONTENT CAUSED BY DIRECT AND RESIDUAL EFFECT OF MEAT AND BONE MEAL
}

\author{
Anna Nogalska \\ Chair of Agricultural Chemistry and Environmental Protection \\ University of Warmia and Mazury in Olsztyn
}

\begin{abstract}
Animal meat and bone meals need to be used for crop production since they have been eliminated from feeds in animal nutrition following the breakout of BSE (Bovine Spongiform Encephalopathy) in cattle. The Decision of the Council of the European Union of 4 December 2000 prohibited adding processed animal protein to feeds for cattle, pigs and poultry. In Poland, this ban was imposed by the decision of the government of 1 November 2003. Meat and bone meals can be an alternative source of nutrients to mineral nitrogen and phosphorus fertilizers because they are rich in these two elements; in addition, they contain calcium, micronutrients and organic substance. The objective of this study has been to evaluate the direct and residual effects of meat and bone meal (MBM) applied in different doses on the content of total nitrogen and its mineral forms in soil, which can indicate a potential threat of environmental contamination and demonstdose the uptake of nitrogen by plants. In 2006-2010, field tests were carried out at the Experimental Station in Bałdy, owned by the University of Warmia and Mazury in Olsztyn. The field trials were set up on typical brown soil. The first order experimental factor was the MBM dose $\left(1.0,1.5,2.0\right.$ and $2.5 \mathrm{t} \mathrm{ha}^{-1}$ year $^{-1}$ and $2.0,3.0,4.0$ and $5.0 \mathrm{t}^{-1}$ every two years); the second order factor was the year of the experiment (4 years). The four-year experiment shows that changes in the soil content of mineral nitrogen forms depended on the dose of MBM, species of crops and weather conditions. Meat and bone meal introduced to soil in large doses, irrespective of the frequency of application, caused a significant increase in the soil's richness in total and mineral nitrogen against the mineral fertilization. The content of $\mathrm{N}^{-\mathrm{NO}_{3}}{ }^{-}$in soil increased significantly due to the residual effect of large doses of MBM (4.0 and $5.0 \mathrm{t} \mathrm{ha}^{-1}$ ) and the annual application of $2.5 \mathrm{t} \mathrm{MBM} \mathrm{ha}{ }^{-1}$. All the determined concentrations of $\mathrm{N}_{-} \mathrm{NO}_{3}{ }^{-}$in soil were within the range of very low levels. The lowest content of $\mathrm{N}_{\text {min. }}$ was detected in soil after winter wheat in the third year of the investigations, which was characterized by an uneven distribution of precipitations, and
\end{abstract}

dr inż. Anna Nogalska, Chair of Agricultural Chemistry and Environmental Protection, University of Warmia and Mazury in Olsztyn, Oczapowskiego 8, 10-719 Olsztyn, Poland, e-mail: anna.nogalska@uwm.edu.pl 
the amount of $\mathrm{N}^{-\mathrm{NO}_{3}}{ }^{-}$was the lowest in the first year, after winter triticale. The crops took up more nitrogen from soil enriched with MBM (except for the smallest dose) than from fields given mineral fertilization.

Key words: total and mineral nitrogen, soil, meat and bone meal (MBM), $\mathrm{N}$ uptake.

\title{
ZMIANY ZAWARTOŚCI AZOTU W GLEBIE JAKO EFEKT BEZPOŚREDNIEGO I NASTĘPCZEGO DZIAŁANIA MĄCZKI MIĘSNO-KOSTNEJ
}

\begin{abstract}
Abstrakt
Konieczność rolniczego zagospodarowania mączek zwierzęcych wynika z eliminacji ich jako komponentów paszowych $\mathrm{w}$ żywieniu zwierząt $\mathrm{z}$ powodu wykrycia choroby BSE (Bovine Spongiform Encephalopathy) u bydła. Decyzja Rady UE od 4 grudnia 2000 roku obowiązuje zakaz stosowania przetworzonego białka zwierzęcego do pasz dla bydła, trzody chlewnej i drobiu. W Polsce zakaz ten wprowadzono decyzją rządowa 1 listopada 2003 roku. Mączka mięsno-kostna może być alternatywą dla mineralnych nawozów azotowo-fosforowych, ponieważ jest bogata $\mathrm{w}$ azot i fosfor, a ponadto zawiera wapń, mikroelementy oraz substancję organiczna. Celem pracy była ocena działania bezpośredniego i następczego mączki mięsno-kostnej (MMK) stosowanej w różnych dawkach na zawartość azotu ogólnego i jego mineralnych form w glebie, będących wskaźnikami potencjalnego zagrożenia skażeniem środowiska, oraz na pobranie azotu przez rośliny. Badania polowe przeprowadzono w latach 2006-2010 w Ośrodku Dydaktyczno-Doświadczalnym w Bałdach, należącym do Uniwersytetu Warmińsko-Mazurskiego w Olsztynie, na glebie brunatnej właściwej. Czynnikiem I rzędu była dawka MMK (1,0;1,5; 2,0 i 2,5 t ha-1 rok$^{-1}$ oraz 2,0;3,0;4,0 i 5,0 t ha $^{-1}$ co dwa lata), II rzędu - rok doświadczenia (4 lata). Z czteroletnich badań wynika, że zmiany $\mathrm{w}$ zawartościach mineralnych form azotu w glebie zależały od dawki MMK, gatunku uprawianej rośliny i warunków pogodowych. MMK wprowadzana do gleby w dużych dawkach, niezależnie od częstotliwości stosowania, wpłynęła na istotne zwiększenie jej zasobności w azot ogólny i mineralny, w odniesieniu do nawożenia mineralnego. Zawartość $\mathrm{N}-\mathrm{NO}_{3}{ }^{-} \mathrm{w}$ glebie zwiększyła się istotnie $\mathrm{w}$ wyniku następczego działania dużych dawek mączki (4,0 i 5,0 t ha ${ }^{-1}$ ) oraz po corocznym zastosowaniu 2,5 t $\mathrm{MMK} \mathrm{ha}^{-1}$. Wszystkie oznaczone zawartości $\mathrm{N}_{-\mathrm{NO}_{3}}{ }^{-} \mathrm{w}$ glebie mieściły się $\mathrm{w}$ przedziale bardzo niskiej zawartości. Najmniejsza zawartość $\mathrm{N}_{\min }$ oznaczono $\mathrm{w}$ glebie po pszenicy ozimej $\mathrm{w}$ trzecim roku badań,

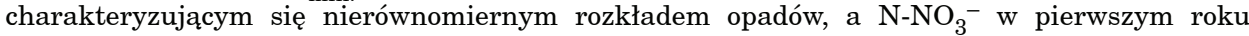
po pszenżycie ozimym. Rośliny pobrały więcej azotu z gleby wzbogacanej MMK (oprócz najmniejszej dawki) niż nawożonej mineralnie.
\end{abstract}

Słowa kluczowe: azot ogólny i mineralny, gleba, mączka mięsno-kostna (MMK), pobranie $\mathrm{N}$.

\section{INTRODUCTION}

Field use of organic waste is an economically and ecologically viable solution. First of all, nutrients enclosed in MBM can be used for crop production. Secondly, MBM improves soil sorption quality. Because less solid or liquid manure is produced and mineral fertilizers are increasingly more expensive, using animal meals as substances rich in nitrogen, phosphorus and organic matter could help to maintain soils' fertility and fecundity (SPYCHAJ- 
-FABISIAK et al. 2007). Meat and bone meals contain nitrogen in the form of protein compounds, so that through mineralization processes the element is slowly released to soil and typically becomes plant available already in the first year of its application (CHAVEs et al. 2005, JENG et al. 2004, 2006, JENG, VAGstad 2009, Nogalska et al. 2012). The dynamics of this process depends on several habitat-related factors and may vary between years and seasons of the year. For over twenty years now, the content of mineral nitrogen in soil has been a recognized test of crops' nutritional demands for this element in many European countries.

The experiment presented in this article involved an analysis of the direct and residual effect of different doses of meat and bone meal on the soil abundance of total and mineral nitrogen and on the uptake of this element by plants in a four-year field rotation. In order to evaluate the environmental effects of soil amendment with large doses of MBM, the content of $\mathrm{N}_{-} \mathrm{NO}_{3}{ }^{-}$in soil was determined in autumn, after harvest.

\section{MATERIAL AND METHODS}

Field trials were carried out at the UWM Experimental Station in Bałdy in 2006-2010. A two-factor experiment was set up with four replications according to the random blocks method. It was established on typical brown soil developed from loamy sand, class IVa, good rye complex in the Polish soil valuation system. The soil was slightly acid $\left(\mathrm{pH}\right.$ in $1 \mathrm{~mol} \mathrm{KCl} \mathrm{dm}{ }^{-3}=$ 6.3). Its mineral composition was as follows: $\mathrm{C}_{\text {org. }} 7.65 \mathrm{~g} \mathrm{~kg}^{-1}, \mathrm{~N}_{\text {og. }} 0.94 \mathrm{~g}$ $\mathrm{kg}^{-1}, \quad \mathrm{~N}_{\text {min. }} 10.25 \mathrm{mg} \mathrm{kg} \mathrm{kg}^{-1}$, and plant available elements (in $\mathrm{mg} \mathrm{kg}^{-1}$ ): 49.0 phosphorus, 96.4 potassium and 31.0 magnesium. The surface area of a plot for harvest was $20 \mathrm{~m}^{2}$. The trials were run in a four-year rotation cycle composed of winter triticale, winter oilseed rape, winter wheat and maize grown for silage. The first order factor was the dose of MBM (1.0, 1.5, 2.0 and $2.5 \mathrm{t} \mathrm{ha}^{-1}$ year ${ }^{-1}$ and 2.0, 3.0, 4.0 and $5.0 \mathrm{t} \mathrm{ha}^{-1}$ every two years); the second order factor was the year of the experiment (4 years). This design of the experiment enabled us to compare the immediate and residual effects of the same dose of meal. The effect of MBM was compared to the result achieved on plots fertilized with mineral NPK fertilizer (mineral fertilization according to the agronomic recommendations for the four test crops). In the mineral fertilization treatment, nitrogen was introduced to soil as urea and ammonium nitrate, while phosphorus was applied in the form of granular triple superphosphate. The meal had a small content of potassium $(3.4 \mathrm{~kg} \mathrm{~K}$ per ton), which is why it was always applied together with additional potassium as $50 \%$ potassium salt in an amount corresponding to the dose applied in the NPK treatment. The doses of nutrients introduced to soil with the mineral fertilizers and MBM are presented in Table 1. The Regulation of the Ministry of Agriculture and Rural Development of 7 December 2004 on 


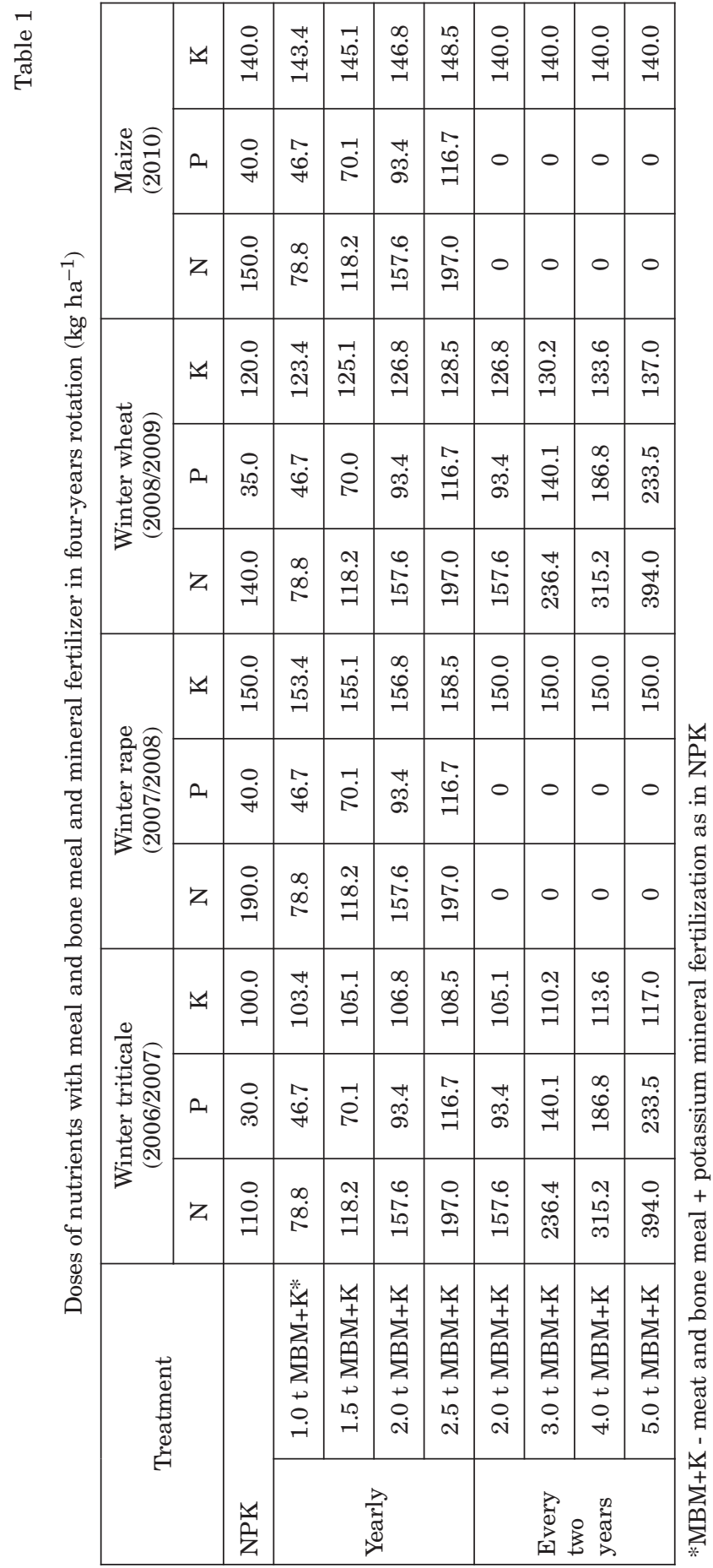


veterinary requirements concerning soil enrichment substances state that a dose of meat and bone meal cannot exceed $5.0 \mathrm{t} \mathrm{ha}^{-1}$ in two years. The animal meal used in our tests was the third category product, i.e. low risk one, and originated from the Animal Waste Utilization Plant owned by Saria Polska in Długi Borek near Szczytno. It contained on average: $965 \mathrm{~g}$ dry matter, $714 \mathrm{~g}$ organic substance, $276 \mathrm{~g}$ crude ash, $137 \mathrm{~g}$ crude fat, $78.8 \mathrm{~g} \mathrm{~N}$, $46.7 \mathrm{~g} \mathrm{P}, 3.42 \mathrm{~g} \mathrm{~K}, 100.3 \mathrm{~g}, \mathrm{Ca}, 6.8 \mathrm{~g} \mathrm{Na}$ and $2.0 \mathrm{~g} \mathrm{Mg} \mathrm{kg}^{-1} \mathrm{~d} . \mathrm{m}$.

After the first year of the experiment (2007) and after the four-year rotation (in 2010), soil samples were taken from the arable horizon (0-30 $\mathrm{cm}$ ) for determination of total nitrogen. Soil tests performed in late autumn are increasingly more useful in the assessment of the environmental impact of nitrogen fertilization, because excessive amounts of mineral nitrogen in soil, especially $\mathrm{N}_{-} \mathrm{NO}_{3}^{-}$, left in soil after harvest may pose a threat to soil and ground waters (FoтумA et al. 2004). In our experiment, the content of ammonia and nitrate nitrogen was tested after harvest each year. Total nitrogen was determined by the Kjeldahl's method, mineral forms of nitrogen were assayed by colorimetry in fresh samples after extraction with $1 \% \mathrm{~K}_{2} \mathrm{SO}_{4}$ solution $\left(\mathrm{N}-\mathrm{NH}_{4}{ }^{+}\right.$with the Nessler's reagent and $\mathrm{N}-\mathrm{NO}_{3}{ }^{-}$with fenoldisulfonic acid). Mineral nitrogen $\left(\mathrm{N}-\mathrm{NH}_{4}{ }^{+}+\mathrm{N}^{-} \mathrm{NO}_{3}{ }^{-}\right.$) was converted into $\mathrm{kg} \mathrm{N}_{\text {min. }}$. $\mathrm{ha}^{-1}$ (Fотума et al. 2004). The results were subjected to an ANOVA analysis of variance in the Statistica 10 software programme, and the significance of differences between arithmetic means was tested with the the Tukey's test at $\alpha=0.05$.

\section{RESULTS AND DISCUSSION}

The analyzed period of time (2006-2010) was characterized by very high variability of the weather conditions (Table 2). The mean temperature from September 2006 to August 2007 was $2.3^{\circ} \mathrm{C}$ higher than the means from the long-term period of 1961-2000. In January 2007, the air temperature was $5.5^{\circ} \mathrm{C}$ higher and the precipitations were four-fold larger than the multiyear means. The deficit of rainfall in April and its excess in July (2.4-fold more than in the multi-year period) were unfavourable for the plant growth and processes of the mineralization of meat and bone meal. The weather conditions in the winter 2008 were much different from the multi-year averages: in January and February the temperature was 3.3 and $4.9^{\circ} \mathrm{C}$ higher, respectively, and the snowfall in January was nearly twice as high as the average. From April to July, the amount of rainfall corresponded to $64.6 \%$ of the multi-year mean for this season of the year. The most severe water deficit appeared in May and June (47\% of the multi-year averages). The distribution of temperatures in 2008-2009 was similar to the multi-year means, but the precipitations were distributed unevenly, being about $30 \%$ 
$\frac{N}{0}$

\begin{tabular}{|c|c|c|c|c|c|c|c|c|c|c|c|c|c|}
\hline \multirow{6}{*}{ 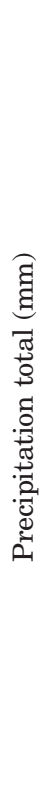 } & 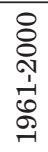 & $\begin{array}{l}\infty \\
\stackrel{\infty}{\sim} \\
\stackrel{N}{0}\end{array}$ & ণ্ণ & $\begin{array}{l}\infty \\
\dot{\leftrightarrow} \\
\stackrel{\leftrightarrow}{0}\end{array}$ & فे & & 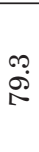 & $\stackrel{\infty}{\mathfrak{D}}$ & స్ & مீ & $\underset{\ddot{q}}{\stackrel{+}{+}}$ & r & $\begin{array}{l}\text { N̦ } \\
\text { ஸे }\end{array}$ \\
\hline & $\stackrel{\circ}{\circ}$ & $\stackrel{+!}{\rightarrow}$ & $\begin{array}{l}10 \\
\stackrel{1}{N}\end{array}$ & ê & $\stackrel{\substack{\infty \\
\infty}}{\infty}$ & חִ & 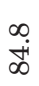 & $\stackrel{+!}{\infty}$ & $\begin{array}{l}\text { ஸे } \\
\text { बें }\end{array}$ & بْ & $\stackrel{\text { H. }}{\mathrm{H}}$ & $\stackrel{+!}{\stackrel{+}{\sim}}$ & مָ \\
\hline & ᄋ్ల & $\stackrel{\sim}{\stackrel{N}{N}}$ & ri & $\underset{10}{\stackrel{0}{0}}$ & $\stackrel{\infty}{+}$ & $\begin{array}{l}\text { คి } \\
\text { กิ }\end{array}$ & 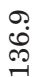 & $\begin{array}{l}\infty \\
\infty \\
\infty\end{array}$ & $\stackrel{\leftrightarrow}{\stackrel{m}{\sigma}}$ & ㅁํㅇ & $\begin{array}{l}1 \\
10 \\
10\end{array}$ & $\begin{array}{l}\infty \\
\stackrel{\rho}{\forall}\end{array}$ & @̊ \\
\hline & 串 & ڤִ & $\stackrel{\sim}{\sim}$ & $\begin{array}{l}+4 \\
\text { เें }\end{array}$ & $\frac{+!}{\text { m. }}$ & 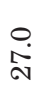 & กิ่ & 次 & 겅 & $\begin{array}{l}\stackrel{\leftrightarrow}{\mathrm{N}} \\
\stackrel{\mathrm{N}}{ }\end{array}$ & $\begin{array}{l}\infty \\
\text { ఎ } \\
\infty\end{array}$ & ণ্ড & 10. \\
\hline & 동 & 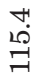 & ஸें & $\stackrel{\infty}{\stackrel{N}{N}}$ & $\stackrel{\sim}{\stackrel{H}{N}}$ & فุ & $\stackrel{-1}{\infty}$ & $\stackrel{\sim}{\mathscr{N}}$ & $\begin{array}{l}0 \\
\infty \\
0\end{array}$ & مْ مْ & ़ֻ & 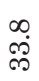 & $\stackrel{\infty}{\stackrel{\infty}{N}}$ \\
\hline & ஓ & $\stackrel{\infty}{\infty}$ & $\stackrel{0}{\stackrel{\leftrightarrow}{N}}$ & ○े & 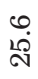 & $\stackrel{\sim}{\infty}$ & ণ़ & ๙ุ & $\begin{array}{l}0 \\
0 \\
0 \\
0\end{array}$ & 엄 & $\begin{array}{l}\infty \\
\infty \\
\infty \\
\infty\end{array}$ & $\stackrel{\infty}{2}$ & $\begin{array}{l}+1 \\
10\end{array}$ \\
\hline \multirow{6}{*}{ 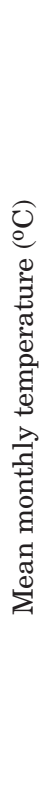 } & 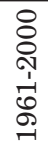 & ণ़่ & $\underset{\sim}{*}$ & $\stackrel{\sim}{\sim}$ & ๑ִ & ํํㄱ & $\begin{array}{l}\text { बి } \\
\stackrel{0}{-1}\end{array}$ & 듣 & ָָ & ำ & $\stackrel{\infty}{\sim}$ & $\stackrel{\sim}{*}$ & זִ \\
\hline & $\stackrel{\circ}{\circ}$ & $\stackrel{\circ}{\text { p) }}$ & $\stackrel{p}{0}$ & 겅 & $\not{\infty}$ & $\stackrel{\circ}{\circ}$ & ڤே. & 오 & $\stackrel{\leftrightarrow}{\stackrel{m}{\sigma}}$ & $\begin{array}{l}0 \\
\stackrel{ }{-}\end{array}$ & 웅 & $\stackrel{+!}{+!}$ & $\begin{array}{l}\infty \\
\varphi^{\circ}\end{array}$ \\
\hline & ஓి & ִָ & $\stackrel{0}{\circ}$ & ـִ & $\stackrel{+!}{\circ}$ & $\begin{array}{l}\text { H. } \\
\stackrel{\sim}{\sim}\end{array}$ & $\stackrel{\text { बִ }}{\vec{H}}$ & ণ্ণ & $\begin{array}{l}0 \\
\end{array}$ & $\stackrel{\sim}{+}$ & $\begin{array}{l}\infty \\
10 \\
10\end{array}$ & 웅 & \\
\hline & ᄋ̊ & $\stackrel{+!}{0}$ & ஸे & $\stackrel{\infty}{\infty}$ & $\stackrel{N}{N}$ & $\begin{array}{l}\text { ๓ִ } \\
\stackrel{1}{\sim}\end{array}$ & 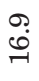 & $\begin{array}{l}20 \\
\infty \\
-1\end{array}$ & 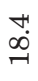 & 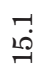 & $\underset{\infty}{\infty}$ & $\stackrel{\circ}{+}$ & $\ddot{0}$ \\
\hline & 응 & $\begin{array}{l}0 \\
\text { ง }\end{array}$ & $\begin{array}{l}10 \\
\stackrel{10}{\top}\end{array}$ & $\begin{array}{l}0 \\
0\end{array}$ & $\stackrel{1}{L}$ & $\begin{array}{l}\infty \\
\stackrel{\infty}{-1}\end{array}$ & $\stackrel{\sim}{\sim}$ & $\stackrel{\sim}{\sim}$ & $\begin{array}{l}\infty \\
\infty \\
-1\end{array}$ & $\begin{array}{l}\stackrel{0}{ } \\
\stackrel{1}{-}\end{array}$ & $\stackrel{1}{1}$ & חִ & $\stackrel{10}{0}$ \\
\hline & $\begin{array}{l}\wp \\
\stackrel{ᄋ}{\circ}\end{array}$ & $\begin{array}{l}10 \\
\infty \\
\infty\end{array}$ & $\stackrel{m}{m}$ & זִ & $\stackrel{\leftrightarrow}{\sim}$ & مْ & $\underset{0}{0}$ & 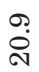 & $\stackrel{N}{ָ}$ & $\underset{+}{+}$ & $\stackrel{\rho}{\sigma}$ & 'י) & $\stackrel{m}{\forall}$ \\
\hline \multicolumn{2}{|c|}{ 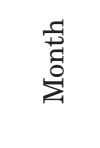 } & 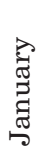 & 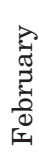 & 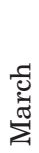 & 胥 & $\stackrel{\vec{\sigma}}{\Sigma}$ & $\stackrel{Ð}{\Xi}$ & $\frac{\vec{\sigma}}{\overrightarrow{3}}$ & 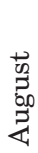 & 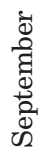 & $\begin{array}{l}\tilde{ठ} \\
\stackrel{0}{0} \\
\stackrel{+}{0} \\
0\end{array}$ & 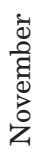 & 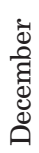 \\
\hline
\end{tabular}


lower than the multi-year average, which may have been responsible for the lower content of mineral nitrogen in soil assayed in that season of the experiment (Table 3). More intensive rainfalls occurred in March (nearly twice as much as on average), but they were followed by a severe water deficit in April (13\% of the multi-year average rainfall). Apart from a cooler $\left(0.7^{\circ} \mathrm{C}\right.$ lower temperature than the multi-year mean) and rainy (2.5-fold more rains than on average) May, the year 2010 did not diverge from the multiyear means.

Table 3

Direct and residual effect of MBM doses on the content of mineral nitrogen $\left(\mathrm{N}_{\min }\right)$ in soil $\left(\mathrm{kg} \mathrm{ha}^{-1}\right)$

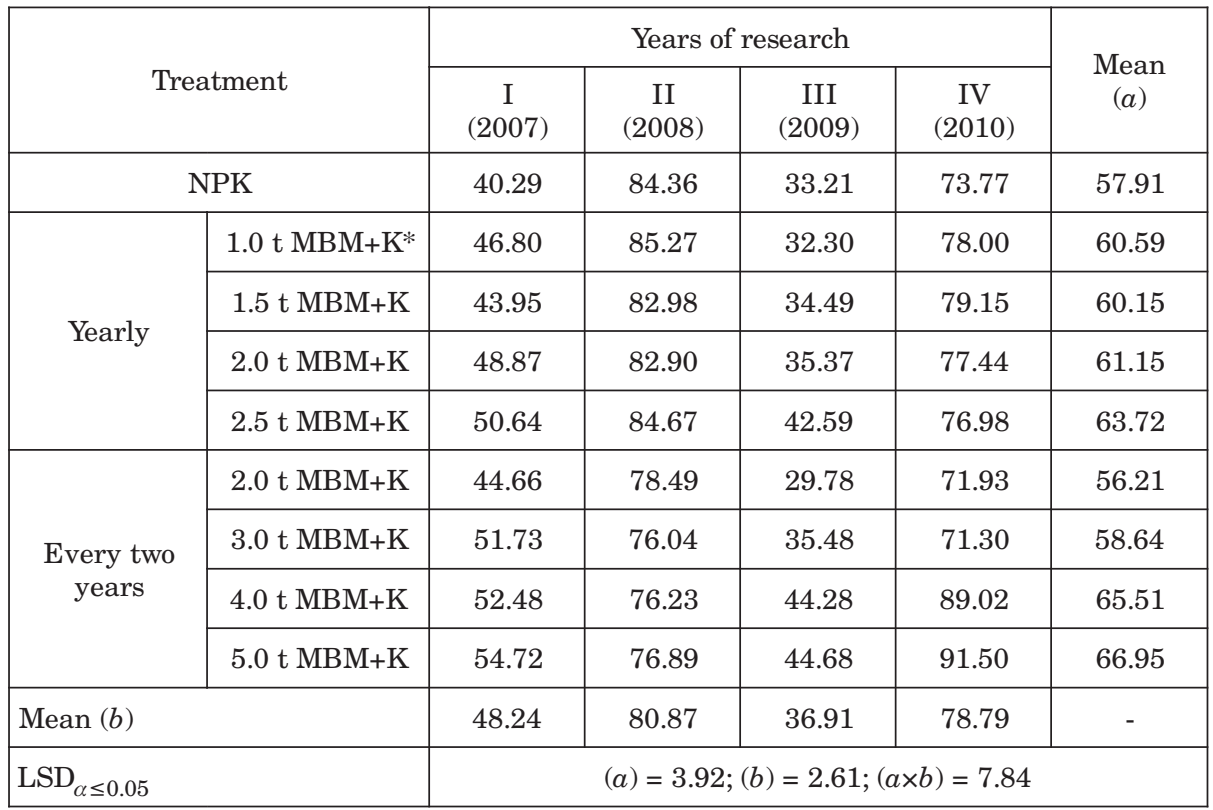

Legend: $a-$ MBM dose, $b-$ years of research, $a \times b-$ interaction

* $\mathrm{MBM}+\mathrm{K}-$ meat and bone meal + potassium mineral fertilizatio as in NPK

Recapitulating, the meteorological conditions during the four-year period of our experiment were changeable, especially in terms of the unevenly distributed precipitations. The growth and development of the plants took place at temperatures about $1^{\circ} \mathrm{C}$ higher than the mean temperatures from the years 1961-2000. The high temperatures during our experiment should have had positive influence on the mineralization and activation of nutrients from meat and bone meal, but the variable amounts of rain, especially in the first and third year did not aid the process. KLIMEK (2006) and BASSIRIRAD (2000) claim that the soil temperature together with its moisture con- 
tent significantly affect the rate of metabolic processes in soil organisms which participate in mineralization of organic matter and in microorganisms which have an indirect influence on the rate of organic matter decomposition. During the degradation of organic matter from natural and organic fertilizers, only a certain share of the nutrients is released immediately, while the remaining amounts, especially of nitrogen, are transiently bound (the immobilization process) by soil microorganisms, an effect which to a large extent prevents losses of nutrients.

Over $90 \%$ of the nitrogen found in the surface layer of soil is present in organic compounds, which is why there is a close dependence between the content of these compounds and total nitrogen (SPYCHAJ-FABISIAK et al. 2007). In our study, the mean content of nitrogen before the experiment equalled $0.94 \mathrm{~g} \mathrm{~kg}^{-1}$ d.m. About $79 \mathrm{~kg} \mathrm{~N} \mathrm{ha}^{-1}$ was introduced to soil with one ton of MBM. After the four-year rotation cycle, the soil enriched with mineral fertilizers contained slightly less nitrogen: $0.90 \mathrm{~g} \mathrm{~N}_{\mathrm{og}} \mathrm{kg}^{-1}$, while the soil nourished with meat and bone meal had about $17 \%$ more nitrogen than initially (Table 4). Compared with the NPK treatment, MBM added in the highest doses (2.0 and 2.5 t ha ${ }^{-1}$ ) every year and in the doses of 3.0, 4.0 and 5.0 t $\mathrm{ha}^{-1}$ every other year caused a significant increase in the content of total nitrogen in soil. The smallest dose $\left(1.0 \mathrm{t} \mathrm{ha}^{-1}\right)$ of MBM stabilized the con-

Table 4

Direct and residual effect of MBM doses on the content of total nitrogen $\left(\mathrm{N}_{\text {tot }}\right)$ in soil ( $\mathrm{g} \mathrm{kg}^{-1}$ d.m.)

\begin{tabular}{|c|c|c|c|c|}
\hline \multirow{2}{*}{\multicolumn{2}{|c|}{ Treatment }} & \multicolumn{2}{|c|}{ Years of research } & \multirow{2}{*}{$\begin{array}{l}\text { Mean } \\
\quad(a)\end{array}$} \\
\hline & & I (2007) & IV (2010) & \\
\hline \multicolumn{2}{|c|}{ NPK } & 0.952 & 0.902 & 0.927 \\
\hline \multirow{4}{*}{ Yearly } & $1.0 \mathrm{t} \mathrm{MBM}+\mathrm{K}^{*}$ & 0.920 & 0.945 & 0.932 \\
\hline & $1.5 \mathrm{t} \mathrm{MBM}+\mathrm{K}$ & 0.995 & 0.960 & 0.977 \\
\hline & $2.0 \mathrm{t} \mathrm{MBM}+\mathrm{K}$ & 0.983 & 1.105 & 1.044 \\
\hline & $2.5 \mathrm{t} \mathrm{MBM}+\mathrm{K}$ & 1.007 & 1.250 & 1.129 \\
\hline \multirow{4}{*}{ Every two years } & $2.0 \mathrm{t} \mathrm{MBM}+\mathrm{K}$ & 1.065 & 0.870 & 0.966 \\
\hline & $3.0 \mathrm{t} \mathrm{MBM}+\mathrm{K}$ & 1.205 & 1.132 & 1.169 \\
\hline & $4.0 \mathrm{t} \mathrm{MBM}+\mathrm{K}$ & 1.235 & 1.265 & 1.250 \\
\hline & $5.0 \mathrm{t} \mathrm{MBM}+\mathrm{K}$ & 1.327 & 1.307 & 1.317 \\
\hline \multicolumn{2}{|l|}{ Mean $(b)$} & 1.077 & 1.082 & - \\
\hline \multicolumn{2}{|l|}{$\operatorname{LSD}_{\alpha \leq 0.05}$} & \multicolumn{3}{|c|}{$(a)=0.109 ;(b)=$ n.s.; $(a \times b)=0.154$} \\
\hline
\end{tabular}

Explanations as in Table 3

$* \mathrm{MBM}+\mathrm{K}-$ meat and bone meal + potassium mineral fertilization as in NPK n.s. - non-significant 
tent of total nitrogen, while the application of 2.0 tons of MBM every other year resulted in a significant decrease in this element in soil in the final year. The highest dose of MBM (2.5 $\mathrm{t} \mathrm{ha}^{-1}$ ) applied annually differentiated the content of total $\mathrm{N}$ in soil to a higher degree than the dose of 5.0 tons of meal introduced to soil every other year. An increase in the content of total nitrogen under the influence of various types of waste from the animal processing industry has also been observed by other researchers (BoHACz, KorniŁŁowicz-Kowalska 2005, Jeng et al. 2006, Spychaj-FABisiaK et al. 2007). In contrast, STĘPIEŃ and MERCIK (2002) completed a pot experiment, in which they determined similar concentrations of total nitrogen in soil fertilized with animal meals or fat waste and in soil treated with farmyard manure.

As the dose of MBM increased, irrespective of the frequency of application, a gradual increase in the content of mineral nitrogen in soil was reported (Table 3). Compared to the NPK treatment (110 kg N ha ${ }^{-1}$ ), the content of $\mathrm{N}_{\text {min. }}$ rose significantly in soil which received the highest dose of meal $2.5 \mathrm{t} \mathrm{ha}^{-1}$ (197 kg $\mathrm{N} \mathrm{ha}^{-1}$ ) every year or the doses of $4.0 \mathrm{t} \mathrm{ha} \mathrm{ha}^{-1}$ (315 kg $\left.\mathrm{N} \mathrm{ha}^{-1}\right)$ and $5.0 \mathrm{t} \mathrm{ha}^{-1}\left(394 \mathrm{~kg} \mathrm{~N} \mathrm{ha}^{-1}\right)$ applied every other year. Less mineral nitrogen than in the control was found only in the treatment with the smallest dose of meal $\left(2.0 \mathrm{t} \mathrm{ha}^{-1}\right)$, which contributed to soil $157.6 \mathrm{~kg}$ $\mathrm{N} \mathrm{ha}^{-1}$ once every other year. Noteworthy is the fact that although fertilization with the higher doses of MBM led to a statistically confirmed increase in the quantity of easily available forms of nitrogen compared to the NPK fertilization, the differences were small, ranging between 6 and $9 \mathrm{~kg} \mathrm{~N}$ $\mathrm{ha}^{-1}$. The results obtained by BoHACZ and KoRNIŁŁOWICZ-KowALsKA (2005) prove that composts made from feathers, bark and straw caused an increase in the content of mineral nitrogen, which occurred with the passage of time since application. In our experiment, we were able to demonstrate evident differences in the concentrations of mineral nitrogen in soil between the years of the experiment. A significantly higher (nearly twice as much) content of mineral nitrogen forms in soil in the second and fourth year of the experiment was proven, regardless of the frequency of MBM application, compared with the other two years. This can be explained by a relatively long process of mineralization of the organic compounds with nitrogen found in meal, which take two years to decompose, as implied by the results reported by SPYCHAJ-FABISIAK et al. (2007) or BoHACZ and KoRNIŁŁOWICZ-KowALSKA (2005). In turn, JENG et al. $(2004,2006)$ believe that as much as $80 \%$ of the nitrogen in MBM is released and becomes available to plants in the first year. Mineralization of organic nitrogen compounds in soil results in the release of mineral nitrogen, whose assimilability depends on its form, weather conditions and the species of crops (BASSIRIRAD 2000). In our trials, winter oilseed rape grown in the second year did not use up the excessive supply of nitrogen. Amounts of nitrogen taken up by oilseed rape were significantly lower (on average $131.09 \mathrm{~kg} \mathrm{~N} \mathrm{ha}^{-1}$ ) than amounts absorbed by the other crops (Table 5). A relatively high concentration of $\mathrm{N}_{\text {min. }}$ was determined in 
Table 5

Direct and residual effect of MBM doses on the uptake nitrogen of plants ( $\mathrm{kg} \mathrm{N} \mathrm{ha}^{-1}$ )

\begin{tabular}{|c|c|c|c|c|c|c|}
\hline \multicolumn{2}{|c|}{ Treatment } & $\begin{array}{c}\text { Winter } \\
\text { triticale } \\
(2006 / \\
/ 2007)\end{array}$ & $\begin{array}{l}\text { Winter } \\
\text { rape } \\
(2007 / \\
/ 2008)\end{array}$ & $\begin{array}{l}\text { Winter } \\
\text { wheat } \\
(2008 / \\
\text { /2009) }\end{array}$ & $\begin{array}{l}\text { Maize } \\
(2010)\end{array}$ & $\begin{array}{l}\text { Mean } \\
\quad(a)\end{array}$ \\
\hline \multicolumn{2}{|c|}{ NPK } & 165.31 & 104.61 & 164.72 & 205.73 & 160.09 \\
\hline \multirow{4}{*}{ Yearly } & $1.0 \mathrm{t} \mathrm{MBM}+\mathrm{K}^{*}$ & 124.59 & 128.40 & 135.30 & 187.77 & 144.01 \\
\hline & $1.5 \mathrm{t} \mathrm{MBM}+\mathrm{K}$ & 164.37 & 149.90 & 166.13 & 194.76 & 168.79 \\
\hline & $2.0 \mathrm{t} \mathrm{MBM}+\mathrm{K}$ & 153.67 & 123.80 & 162.73 & 242.04 & 170.56 \\
\hline & $2.5 \mathrm{t} \mathrm{MBM}+\mathrm{K}$ & 157.35 & 133.67 & 192.73 & 242.20 & 181.49 \\
\hline \multirow{4}{*}{ Every two years } & $2.0 \mathrm{t} \mathrm{MBM}+\mathrm{K}$ & 126.38 & 137.49 & 185.60 & 180.22 & 157.42 \\
\hline & $3.0 \mathrm{t} \mathrm{MBM}+\mathrm{K}$ & 147.50 & 148.80 & 216.49 & 228.14 & 185.23 \\
\hline & $4.0 \mathrm{t} \mathrm{MBM+K}$ & 143.31 & 118.16 & 205.12 & 191.07 & 164.42 \\
\hline & $5.0 \mathrm{t} \mathrm{MBM}+\mathrm{K}$ & 151.51 & 134.99 & 235.02 & 198.46 & 179.99 \\
\hline \multicolumn{2}{|l|}{ Mean $(b)$} & 148.22 & 131.09 & 184.87 & 207.82 & - \\
\hline \multicolumn{2}{|l|}{$\mathrm{LSD}_{\alpha \leq 0.05}$} & \multicolumn{5}{|c|}{$(a)=15.85 ;(b)=10.57 ;(a \times b)=31.70$} \\
\hline
\end{tabular}

Explanations as in Table 3

* MBM+K - meat and bone meal + potassium mineral fertilization as in NPK

soil in the last year of the experiment, after harvesting maize, a plant with the highest nutritional demand (an average uptake of $207.82 \mathrm{~kg} \mathrm{~N} \mathrm{ha}^{-1}$ ) among the cultivated crops. Also, higher concentrations of $\mathrm{N}_{\text {min. }}$. were determined in the control treatment after the harvest of winter oilseed rape and maize, whose post-harvest residues could have become an additional source of nitrogen (Table 6). This result cannot be explained by the accumulation of nitrogen gradually released from meal because the supply of nitrogen in the third year was the smallest, clearly due to the unfavourable distribution of precipitations and relatively large amounts of nitrogen absorbed by winter wheat (on average $184.87 \mathrm{~kg} \mathrm{~N} \mathrm{ha}^{-1}$ ) - Table 5. Under controlled, laboratory conditions corresponding to the natural temperatures in autumn in spring, Delin and Engstrom (2010) showed that $65 \%$ of the nitrogen embedded in organic compounds found in meat and bone meal becomes phytoavailable after 35-50 days of mineralization. Also, ChAves et al. (2005) report that $43-64 \%$ of the nitrogen in organic compounds in five types of animal meals was mineralized during 20 -day-long incubation of soil.

Nitrogen is considered to be the most important yield stimulating element. But it can also turn into the most severe threat to the natural environment. Particularly dangerous are mineral forms of nitrogen, especially 
Table 6

Direct and residual effect of MBM doses on the content of nitrate nitrogen $\left(\mathrm{N}^{-\mathrm{NO}_{3}}{ }^{-}\right)$ in soil $\left(\mathrm{kg} \mathrm{ha}^{-1}\right)$

\begin{tabular}{|c|c|c|c|c|c|c|}
\hline \multirow{2}{*}{\multicolumn{2}{|c|}{ Treatment }} & \multicolumn{4}{|c|}{ Years of research } & \multirow{2}{*}{$\begin{array}{c}\text { Mean } \\
(a)\end{array}$} \\
\hline & & $\begin{array}{c}\mathrm{I} \\
(2007)\end{array}$ & $\begin{array}{c}\text { II } \\
(2008)\end{array}$ & $\begin{array}{c}\text { III } \\
(2009)\end{array}$ & $\begin{array}{c}\text { IV } \\
(2010)\end{array}$ & \\
\hline \multicolumn{2}{|c|}{ NPK } & 13.55 & 31.87 & 22.86 & 27.39 & 23.92 \\
\hline \multirow{4}{*}{ Yearly } & $1.0 \mathrm{t} \mathrm{MBM}+\mathrm{K}^{*}$ & 15.87 & 32.88 & 21.23 & 27.12 & 24.28 \\
\hline & $1.5 \mathrm{t} \mathrm{MBM}+\mathrm{K}$ & 17.68 & 28.99 & 22.02 & 26.98 & 23.92 \\
\hline & $2.0 \mathrm{t} \mathrm{MBM}+\mathrm{K}$ & 17.08 & 25.83 & 27.32 & 31.15 & 25.34 \\
\hline & $2.5 \mathrm{t} \mathrm{MBM}+\mathrm{K}$ & 19.62 & 31.67 & 31.23 & 30.49 & 28.25 \\
\hline \multirow{4}{*}{ Every two years } & $2.0 \mathrm{t} \mathrm{MBM}+\mathrm{K}$ & 14.68 & 24.12 & 18.58 & 26.70 & 21.02 \\
\hline & $3.0 \mathrm{t} \mathrm{MBM}+\mathrm{K}$ & 20.32 & 22.17 & 24.60 & 30.69 & 24.45 \\
\hline & $4.0 \mathrm{t} \mathrm{MBM}+\mathrm{K}$ & 23.17 & 25.57 & 32.31 & 28.50 & 27.39 \\
\hline & $5.0 \mathrm{t} \mathrm{MBM}+\mathrm{K}$ & 23.77 & 24.01 & 32.50 & 28.38 & 27.17 \\
\hline \multicolumn{2}{|l|}{ Mean $(b)$} & 18.42 & 27.46 & 25.85 & 28.60 & - \\
\hline \multicolumn{2}{|l|}{$\operatorname{LSD}_{\alpha \leq 0.05}$} & \multicolumn{5}{|c|}{$(a)=2.45 ;(b)=1.63 ;(a \times b)=4.90$} \\
\hline
\end{tabular}

Explantations as in Table 3

$* \mathrm{MBM}+\mathrm{K}-$ meat and bone meal + potassium mineral fertilization as in NPK

nitrates, whose large amounts are transferred deep into the soil profile (GrabiśsKa et al. 2005). The unwanted effect of nitrogen can appear when the applied doses of mineral or natural nitrogen fertilizers are in excess of the agronomic recommendations. The introduction of meat and bone meal to soil in our experiment resulted in a higher content of ammonia than nitrate nitrogen (Tables 3,6 ). It should be underlined that this result was achieved in soil sampled after the vegetative season (September), when the process of $\mathrm{N}^{-\mathrm{NO}_{3}}{ }^{-}$leaching in the autumn and winter season is typically more intensive. It can be therefore assumed that the application of MBM has positive influence on the soil environment, because ammonia ions are rather strongly adsorbed by soil. Contrary results were reported by BoHACZ and KoRNiŁŁowicz-KowaLSKA (2005). In our experiment, significantly higher quantities of nitrates in soil appeared in response to the doses of 4.0 and $5.0 \mathrm{t} \mathrm{MBM} \mathrm{ha}{ }^{-1}$ introduced every other year and the highest annual dose $\left(2.5 \mathrm{t} \mathrm{MMK} \mathrm{ha}^{-1}\right.$ ) than in soil which received mineral fertilization (Table 6). Nonetheless, even the highest determined amounts of $\mathrm{N}_{-} \mathrm{NO}_{3}{ }^{-}$in soil were within the threshold levels deemed as a very low content of nitrogen by the Regional Agricultural and Chemical Stations, based on the results of monitoring observations of arable soils from 5.000 checkpoints across Poland 
(Fотума et al. 2004). It was also verified that the year of the experiment had a significant influence on the content of ammonia nitrogen, which occurred in the lowest amounts in soil after the harvest of triticale (first year). This was most probably due to the uneven distribution of precipitations and a very short time period of the mineralization of nitrogen bound in organic compounds in meat and bone meal. Better stability of nitrates in soil, especially in the second year of the tests, was demonstrated after an annual application of animal meal.

The factors which influenced the abundance of mineral nitrogen compounds in soil were the high doses of MBM, species of the grown crop and weather conditions. Relatively small quantities of $\mathrm{N}_{-} \mathrm{NO}_{3}{ }^{-}$in soil suggest a low risk of environmental contamination with this element. They can also indirectly imply that there is some deficit of plant available nitrogen in soil. However, compared to mineral fertilization, it was only the smallest dose of MBM (1.0 t ha ${ }^{-1}$ a year $2.0 \mathrm{t} \mathrm{ha}^{-1}$ every other year) that resulted in a lower uptake of nitrogen by the grown crops (Table 6). Besides, meal introduced to soil in the highest dose every year or in the doses of 3.0 and $5.0 \mathrm{t} \mathrm{ha}^{-1}$ every two years caused a significantly higher uptake of nitrogen by plants against the NPK treatment. JENG and VAGSTADT (2009) do not recommend application of animal meals in early spring or late autumn due to possible leaching of nitrates, even though in a lysimetric experiment they conducted the amounts of nitrates leached from soil fertilized with animal meals were half the quantities leached from soil fertilized with mineral preparations.

\section{CONCLUSIONS}

1. The content of mineral nitrogen forms in soil depended on the dose of meat and bone meal, species of the grown crop and the weather conditions.

2. Meat and bone meal applied in high doses, irrespective of the frequency of application, significantly raised the soil abundance of total and mineral nitrogen versus mineral fertilization. All the determined concentrations of $\mathrm{N}^{-\mathrm{NO}_{3}}{ }^{-}$in soil were within the levels corresponding to a very low content.

3. The smallest concentration of $\mathrm{N}_{\min }$. was determined in soil after winter wheat cultivation, in the third year of the experiment, which was characterized by an uneven distribution of precipitations. The smallest amount

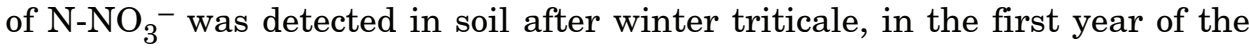
trials. Meal introduced to soil in very high doses raised the uptake of nitrogen by plants compared the treatment with mineral fertilization. 


\section{REFERENCES}

BASSIRIRAD H. 2000. Kinetics of nutrient uptake by roots: responses to global changes. New Phytol., 147: 155-169.

Bohacz J., KoRniŁeowicz-Kowalska T. 2005. Influence of keratin-bark and keratin-bark-straw composts on properties of selected soils. Part II. Chemical properties. Zesz. Probl. Post. Nauk. Rol., 506, 65-76. (in Polish)

Chaves C., Canet R., Albiach R., Marin J., Pomares F. 2005. Meat and bone meal: fertilizing value and doses of nitrogen mineralization. Nutrient and carbon cycling in sustainable plant-soil systems. Proc. of $11^{\text {th }}$ Int. Conf. Ramiran. Murcia, October 2004, 1 (6-9): 177-180.

Delin S., Engstrom L. 2010. Timing of organic fertilizer to synchronie nitrogen supply with crop demand. Acta Agric. Scand., Se. B-Soil and Plant Science, 60(1): 78-88.

Fотума E., Fотума M., Рietruch Cz. 2004. The content of mineral nitrogen in the soils of Poland. Nawozy i Nawożenie, 3(20): 11-54. (in Polish)

Grabińska B., Koc J., Glińska-Lewczuk K. 2005. Seasonal export of nitrate nitrogen from agricultural-forested catchments. J. Elementol., 10(2): 277-288.

Jeng A.S., Haraldsen T.K., Vagstad N., GrŘnlund N. 2004. Meat and bone meal as nitrogen fertilizer to cereals in Norway. Agric. Food Sci., 13: 268-275.

Jeng A. S., Haraldsen T. K., GrŘnlund A., Pedersen P. A. 2006. Meat and bone meal as nitrogen and phosphorus fertilizer to cereals and ryegrass. Nutr. Cyc. Agroecosys., 76: 183-191.

Jeng A.S., VAGSTAD N. 2009. Potential nitrogen and phosphorus leaching from soils fertilized with meat and bone meal. Acta Agric. Scand., Se. B-Soil and Plant Science, 59(3): 238-245 .

KLIMEK B. 2006. Effect of temperature on the dose and decomposition processes of organic matter in soil. Wiad. Ekol., 52(3): 123-142. (in Polish)

Nogalska A., Czapla J., Nogalski Z., Skwierawska M. Kaszuba M. 2012. The effect of increasing doses of meat and bone meal (MBM) on maize (Zea mays L.) grown for grain. Agric. Food Sci., 21: 325-331.

Spychaj-Fabisiak E., Kozera W., Majcherczak E., Ralcewicz M., Knapkowski T. 2007. Evaluation of light soil fertility after the application of organic wase and manure. Acta Sci. Pol., Agricultura 6(3): 69-76. (in Polish)

StęPień W., Mercik S. 2002. Fertilization value of animal product processing wastes. Zesz. Probl. Post. Nauk. Rol., 484: 595-600. (in Polish) 